\author{
MATEUSZ ŻABA
}

ORCID: 0000-0002-3636-6456

Uniwersytet Śląski w Katowicach

\title{
O POTRZEBIE IMPLEMENTACJI DO PRAWA POLSKIEGO PRZEPISÓW DOTYCZĄCYCH TRANSGRANICZNEGO PODZIAŁU SPÓŁEK KAPITAŁOWYCH (UWAGI NA TLE DOTYCHCZASOWYCH ROZWIĄZAŃ CZESKICH)
}

\begin{abstract}
Abstrakt: Polski ustawodawca został postawiony przed koniecznością implementacji nowych uregulowań dotyczących podziału transgranicznego. Uregulowania te, niezbędne do wykonania dyrektywy 2019/2121/UE, powinny zostać wprowadzone w życie najpóźniej do 31 stycznia 2023 roku. W związku z tym głównym celem niniejszego opracowania jest analiza procedury transgranicznego podziału zaproponowanej przez ustawodawcę europejskiego we wspomnianej dyrektywie i porównania jej z rozwiązaniami czeskimi, które obowiązują obecnie. W artykule odniesiono się także do miejsca transponowania przepisów, definicji legalnej połączenia transgranicznego oraz zakresu samej regulacji.
\end{abstract}

Słowa kluczowe: podziały transgraniczne, implementacja dyrektywy 2019/2121/UE, prawo czeskie, definicja legalna podziałów

\section{WSTĘP}

Ustawodawca europejski na mocy dyrektywy Parlamentu Europejskiego i Rady (UE) 2019/2121 z 27 listopada 2019 roku$^{1}$ dokonał istotnej zmiany dotychczasowych przepisów dyrektywy 2017/1132 w sprawie niektórych aspektów

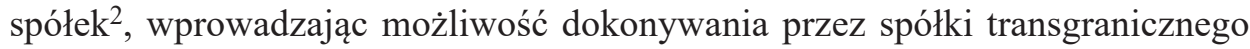
przekształcenia bądź podziału. Regulacja unijna wyszła w ten sposób naprzeciw faktycznym potrzebom rynku. Jest to istotne, ponieważ dyskusje z przedsiębiorcami na temat przeprowadzania innych niż połączenie transgranicznych procesów transformacyjnych były prowadzone od dłuższego czasu ${ }^{3}$. Wskutek przyjęcia

${ }^{1}$ Dz.Urz. UE L 321 z 12.12.2019 r., s. 1; dalej: dyrektywa 2019/2121.

2 Dz.Urz. UE L 169 z 30.06.2017 r., s. 46; dalej: dyrektywa 2017/1132.

3 W tym celu z inicjatywy Komisji Europejskiej w okresie od 8 września 2014 do 2 lutego 2015 roku przeprowadzono konsultacje społeczne dotyczące kwestii możliwego skorzystania z nowej formy 
dyrektywy 2019/2121 aktualny katalog możliwych transformacji podmiotowych został poszerzony w stosunku do spółek kapitałowych o nowe formy transgranicznej reorganizacji - transgraniczny podział oraz transgraniczne przekształcenie.

Jak zostało podkreślone w preambule do dyrektywy 2019/2121, dotychczasowy brak prawnych ram dotyczących przekształceń i podziałów transgranicznych prowadził do fragmentacji rozwiązań prawnych i niepewności prawnej, które w konsekwencji tworzyły bariery w korzystaniu ze swobody przedsiębiorczości. Tym samym ustawodawca unijny szczególną uwagę po raz kolejny poświęcił prawu przedsiębiorców i możliwym sposobom realizowania zasady swobody przedsiębiorczości na rynku wewnętrznym Unii Europejskiej. W myśl art. 3 dyrektywy 2019/2121 zobowiązano przy tym państwa członkowskie do transponowania do krajowych porządków prawnych przepisów dotyczących transgranicznych przekształceń i podziałów najpóźniej do 31 stycznia 2023 roku. Harmonizacja na poziomie unijnym przepisów dotyczących transgranicznego podziału z jednej strony ma przyczynić się do zniesienia istniejącego w tym zakresie ograniczenia swobody przedsiębiorczości, a z drugiej ma zapewnić minimum ochrony zainteresowanych podmiotów, takich jak pracownicy, wierzyciele czy wspólnicy spółki uczestniczącej w tej procedurze. W tym miejscu należy podkreślić, że przyjęta przez ustawodawcę unijnego regulacja odnosi się jedynie do podziałów transgranicznych, które wiążą się z tworzeniem nowych spółek (to jest podziału przez rozdzielenie i utworzenie nowych spółek oraz podziału przez wydzielenie i utworzenie nowych spółek $)^{4}$.

Sama koncepcja transgranicznego podziału spółek kapitałowych nie jest novum. Regulacja tej problematyki znana jest bowiem od pewnego czasu niektórym ustawodawcom europejskim, między innymi ustawodawcy czeskiemu ${ }^{5}$, duńskiemu ${ }^{6}$ oraz

trangranicznej reorganizacji przedsiębiorstwa. Więcej na ten temat zob. podsumowanie odpowiedzi udzielonych w ramach publicznych konsultacji w sprawie transgranicznych połączeń i podziałów spółek — październik 2015, http://ec.europa.eu/internal_market/consultations/2014/cross-border-mergers-divisions/docs/summary-of-responses_en.pdf. Zob. także wniosek Komisji Europejskiej z dnia 25 kwietnia 2018 roku do dyrektywy Parlamentu Europejskiego i Rady zmieniającej dyrektywę (UE) 2017/1132 w odniesieniu do transgranicznego przekształcania, łączenia i podziału spółek, s. 15 n., https://eur-lex.europa.eu/legal-content/PL/TXT/PDF/?uri=CELEX:52018PC0241\&from=EN (dostęp: 30.07.2020). Por. też rozważania na temat dopuszczalności podziału transgranicznego przedstawione w: R. Król, Dopuszczalność przeprowadzenia transgranicznego podziału spótki, PPH 2017, nr 4, s. $40-43$.

${ }^{4}$ Zob. pkt 8 preambuly do dyrektywy 2019/2121 oraz art. 160b pkt 3 dyrektywy 2017/1132. Por. także J. Napierała, [w:] System Prawa Handlowego, t. 2b. Prawo spółek handlowych, red. A. Szumański, Warszawa 2019, s. 955.

5 Zob. m.in. § 336a czeskiej ustawy z 19 marca 2008 roku o przemianach spółek handlowych i spółdzielni, czes. Zákon o přeměnách obchodních společností a družstev, Zák. č. 125/2008 Sb.; dalej: PřemZ lub ustawa o przemianach.

6 Zob. m.in. § 291 duńskiej ustawy o spółkach akcyjnych i spółkach z ograniczoną odpowiedzialnością (ustawa o spółkach), duń. Lov om aktie- og anpartsselskaber (selskabsloven), lovbekendtgørelse nr 1089 af 14.09.2015. 
fińskiemu ${ }^{7}$. Ze względu na brak analogicznej regulacji w prawie polskim i postawiony przed polskim ustawodawcą obowiązek transponowania przepisów dotyczących tego sposobu podmiotowej reorganizacji spółek wręcz wskazana wydaje się analiza rozwiązań przyjętych i już stosowanych w innych porządkach prawnych. Badanie dotychczasowych doświadczeń innych ustawodawców w stosowaniu konkretnych przepisów oraz określenie najistotniejszych problemów związanych z ich tworzeniem mogą pomóc $\mathrm{w}$ ustaleniu, czy polski ustawodawca stoi przed koniecznością wyjścia poza minimalny standard harmonizacji przewidziany przepisami 160a-160u dyrektywy 2017/1132. Ze względu na zbliżony poziom rozwoju gospodarczego, sytuację geopolityczną, podobne doświadczenia w związku z transformacją ustrojową i umożliwieniem podejmowania działalności gospodarczej w ramach gospodarki wolnorynkowej oraz ostatecznie przystappienie w tym samym czasie do Unii Europejskiej na szczególną uwagę zasługują rozwiązania obowiązujące już w prawie czeskim. Ze względu na wspomniane cechy możliwości skorzystania z doświadczeń czeskiego ustawodawcy oraz złożoność procedury transgranicznego podziału w artykule podjęto rozważania dotyczące konieczności klarownego uregulowania problematyki transgranicznego podziału w prawie polskim.

\section{MIEJSCE TRANSPONOWANIA PRZEPISÓW ORAZ METODA REGULACJI}

Ustawodawca europejski nie narzuca ustawodawcom krajowym miejsca, w którym są oni zobowiązani uregulować podziały transgraniczne. Wypada ponownie zaznaczyć, że zakreślony został jedynie termin, w jakim państwa członkowskie muszą wprowadzić w życie przepisy ustawowe, wykonawcze i administracyjne niezbędne do wykonania dyrektywy 2019/2121 (to jest do 31 stycznia 2023 roku). W efekcie ustawodawcy krajowi, którzy uregulowali dotychczas problematykę transgranicznego podziału w swoich porządkach prawnych, będą musieli - o ile ich regulacja nie spełnia minimalnego standardu harmonizacyjnego - uzupełnić dotychczasowe przepisy o rozwiązania przewidziane obecnie w przepisach art. 160a-160u dyrektywy 2017/1132.

Miejsce uregulowania transgranicznego podziału będzie tym samym zależeć wyłącznie od systematyki przyjętej przez danego ustawodawcę krajowego. Przykładowo ustawodawca duński uregulował kwestię transgranicznego podziału bezpośrednio w ustawie odnoszącej się do funkcjonowania spółek kapitałowych. Wydzielił on przy tym odrębny rozdział 16 odnoszący się wyłącznie do transgranicznych połączeń i podziałów (duń. grcenseoverskridende fusion og spaltning). Ustawodawca czeski natomiast zasadniczą część dotyczącą transgranicznego

7 Zob. rozdział 17, § 19 fińskiej ustawy z 1 września 2006 roku o spółkach, fiń. Osakeyhtiölaki, ks. L 625/2006. 
podziału uregulował w przepisach ustawy z 19 marca 2008 roku o przemianach spółek handlowych i spółdzielni. Ustawa ta szczegółowo reguluje procedurę łączenia się, podziału, zmiany formy prawnej oraz innych sposobów reorganizacji podmiotowej spółek oraz spółdzielni ${ }^{8}$.

Przepisy dotyczące transgranicznego podziału w prawie czeskim znalazły się bezpośrednio w części III, rozdziale IX (část třetí, hlava IX) wspomnianej ustawy o przemianach. Rozdział ten został poprzedzony przepisami o krajowym podziale spółek i spółdzielni, a te z kolei przepisami ogólnymi o podziale spółek i spółdzielni (§ 243-266a). Należy jednak podkreślić, że czeska regulacja prawna transgranicznego podziału zawarta $\mathrm{w}$ ustawie o przemianach nie jest wyczerpująca i odsyła zarówno do części ogólnej ustawy (to jest do regulacji tak zwanych przemian podmiotowych ${ }^{9}$ ), jak i do przepisów czeskiego kodeksu cywilnego.

Wpływ na obecny kształt czeskich przepisów dotyczących transgranicznego podziału miała nowelizacja ustawy o przemianach dokonana mocą ustawy z 27 października 2011 roku $^{10}$. Na jej podstawie dokonano kompleksowych zmian, wprowadzając między innymi wspomniane przepisy dotyczące transgranicznego podziału (§ 336a-3361), przepisy ogólne co do tak zwanych transgranicznych przemian $(\S 59 \mathrm{a}-59 \mathrm{zb})^{11}$, przepisy o transgranicznym przeniesieniu majątku rozwiązywanej spółki na jedynego wspólnika (§ 359a-359l) oraz szczegółowe przepisy odnoszące się do procedury zmiany wysokości kapitału zakładowego w przypadku połączenia (na przykład § 89-91a dla spółki z o.o. i § 100-111 dla spółki akcyjnej) i podziału (§ 281-283) ${ }^{12}$.

$8 \mathrm{~W}$ myśl $§ 1$ ust. 2 PřemZ pod pojęciem przemiany (czes. preměna) rozumie się łączenie się (czes. fúze) spółki lub spółdzielni, podział (czes. rozdélení) spółki lub spółdzielni, przeniesienie majątku na wspólnika (czes. prevod jmění na společníka), zmianę formy prawnej (czes. změna právní formy) oraz transgraniczne przeniesienie siedziby (czes. přeshraniční přemistění sídla).

9 Więcej na ten temat zob. m.in. R. Pelikán, [w:] S. Černá, I. Štenglová, I. Pelikánová, Právo obchodnich korporací, Praha 2015, s. 251-254; T. Dvořák, Přeměny obchodních korporací, Praha 2015, s. 8-10. Por. także poglądy wyrażane uprzednio w czeskiej doktrynie: J. Glos, O preménách obchodnich společností, „Právní prakse” 1942-1943, s. 3 n.; oraz R. Pelikán, Zákon o prememénách obchodních společností a družstev. Komentár̆, t. 1. §1-179, Praha 2010, s. 12-13.

10 Zákon ze dne 27.10.2011, kterým se mění zákon č. 125/2008 Sb., o přeměnách obchodních společností a družstev, ve znění pozdějších předpisů, a další související zákony, 355/2011 Sb. (pol. czeska ustawa z 27 października 2011 roku, na mocy której dokonuje się zmiany ustawy nr 125/2008 S., o przemianach spółek handlowych i spółdzielni w aktualnym brzmieniu i innych związanych z nią ustaw, 355/2011 Sb.).

11 Znajdują one zastosowanie jako przepisy ogólne do transgranicznego połączenia (czes. preshranični fúze) spółki lub spółdzielni, transgranicznego podziału (czes. preshraniční rozděleni) spółki lub spółdzielni, transgranicznego przeniesienia majątku na wspólnika (czes. preshraniční převod jměni na společníka) oraz transgranicznego przeniesienia siedziby (czes. preshranični premistěni sidla).

12 Więcej na temat tej obszernej nowelizacji czeskiej ustawy o przemianach oraz jej przyczyn zob. J. Dědič, Novinky v právni úpravě preměn obchodních společností a družstev, „Obchodněprávní revue” 2012, nr 1, s. 9 n.; oraz Důvodová zpráva k zákonu č. 355/2011 Sb. kterým se mění zákon č. 125/2008 Sb., o přeměnách obchodních společností a družstev, ve znění pozdějších předpisů, 
Ze względu na systematykę polskiego kodeksu spółek handlowych oraz brak jakichkolwiek wytycznych ustawodawcy europejskiego w zakresie metody implementacji przepisów dotyczących transgranicznego podziału należy uznać, że metoda regulacji przyjęta przez ustawodawcę czeskiego może posłużyć jedynie za pewien wzór dla ustawodawcy polskiego. Najwłaściwszym miejscem do uregulowania transgranicznego podziału w prawie polskim będzie tytuł IV, dział II kodeksu spółek handlowych. Niestety ze względu na brak rozdziałów w ramach wspomnianego działu należy wysunąć postulat de lege ferenda o konieczności wprowadzenia ich na wzór czeskiej regulacji podziału oraz polskiej regulacji łączenia się spółek. W ramach działu II wypada rozważyć wprowadzenie odrębnych rozdziałów: pierwszego - obejmującego przepisy ogólne na temat podziału (to jest art. 528-532 k.s.h.), drugiego - regulującego tak zwany krajowy podział spółek kapitałowych (to jest art. 533-550 ${ }^{1}$ k.s.h.) oraz trzeciego, w którym znalazłyby się przepisy o transgranicznym podziale. Mając na uwadze przejrzystość regulacji, wypadałoby także zastanowić się nad przeniesieniem przepisu art. 550 1 k.s.h. i umiejscowieniem go po art. 541, ale przed art. 542 k.s.h. Przy takim zabiegu legislacyjnym przepisy dotyczące transgranicznego podziału mogłyby być uregulowane $\mathrm{w}$ kolejnych jednostkach redakcyjnych, zaczynając od obecnego art. $550^{1}$ k.s.h.

\section{POJĘCIE TRANSGRANICZNEGO PODZIAŁU}

\section{POJĘCIE TRANSGRANICZNEGO PODZIAŁU W PRAWIE EUROPEJSKIM}

Przepisy dyrektywy 2017/1132 dotyczące transgranicznego podziału znajdują zastosowanie do podziału spółek kapitałowych utworzonych zgodnie z prawem państwa członkowskiego i mających siedzibę, zarząd główny lub główne przedsiębiorstwo na terytorium Unii Europejskiej pod warunkiem, że co najmniej dwie ze spółek kapitałowych uczestniczących w podziale podlegają prawu różnych państw członkowskich. Zaproponowana przez ustawodawcę europejskiego regulacja transgranicznego podziału, jak zostało to już zaznaczone, odnosi się wyłącznie do podziału, wskutek którego dojdzie do utworzenia nowej spółki bądź nowych spółek. W konsekwencji poza zakresem przedmiotowym dyrektywy 2019/2121 znalazł się tak zwany podział przez przejęcie. Ustawodawca europejski przewidział przy tym w przepisie art. 160b pkt 4 dyrektywy 2017/1132 trzy możliwe sposoby podziału spółki. Stosownie do tego przepisu podział spółki może zostać dokonany w drodze czynności, w której:

— spółka podlegająca podziałowi w chwili rozwiązania bez przeprowadzenia postępowania likwidacyjnego przenosi wszystkie swoje aktywa i pasywa na co

a další související zákony, Parlament České republiky, Poslanecká sněmovna, 6. volební období, 30.11.2011, s. $140 \mathrm{n}$. 
najmniej dwie spółki nowo utworzone w zamian za przyznanie wspólnikom spółki podlegającej podziałowi papierów wartościowych lub udziałów albo akcji spółek nowo utworzonych oraz, w stosownych przypadkach, świadczenie pieniężne nieprzekraczające 10\% wartości nominalnej lub, w przypadku braku wartości nominalnej, świadczenie pieniężne nieprzekraczające $10 \%$ wartości księgowej tych papierów wartościowych lub udziałów albo akcji;

— spółka podlegająca podziałowi przenosi część swoich aktywów i pasywów na jedną lub więcej spółek nowo utworzonych w zamian za przyznanie wspólnikom spółki podlegającej podziałowi papierów wartościowych lub udziałów albo akcji spółek nowo utworzonych, spółki podlegającej podziałowi lub zarówno spółek nowo utworzonych, jak i spółki podlegającej podziałowi oraz, w stosownych przypadkach, świadczenie pieniężne nieprzekraczające $10 \%$ wartości nominalnej lub, w przypadku braku wartości nominalnej, świadczenie pieniężne nieprzekraczające $10 \%$ wartości księgowej tych papierów wartościowych lub udziałów albo akcji;

— spółka podlegająca podziałowi przenosi część swoich aktywów i pasywów na jedną lub więcej spółek nowo utworzonych w zamian za emisję na rzecz spółki podlegającej podziałowi papierów wartościowych lub udziałów albo akcji w spółkach nowo utworzonych.

Wypada odnotować, że drugi oraz trzeci ze wskazanych sposobów podziału transgranicznego ze strony formalnoprawnej stanowi tak zwany podział przez wydzielenie z utworzeniem nowej spółki bądź nowych spółek. Ponadto trzeci sposób umożliwia tworzenie struktur holdingowych, ponieważ spółka dzielona zamiast jej wspólników będzie obejmować udziały bądź akcje w spółkach nowo utworzonych.

Należy też zaznaczyć, że ustawodawca europejski umieścił w przepisie art. 160b dyrektywy 2017/1132 siatkę pojęciową, wprowadzając legalne definicje „spółki”, „spółki podlegającej podziałowi” i „spółki przejmującej”. W odniesieniu do legalnej definicji „spółki” na potrzeby transgranicznego podziału posłużono się odesłaniem do załącznika II wskazującego formy spółek, o których jest mowa w poszczególnych przepisach dyrektywy 2017/1132 (art. 160b pkt 1) ${ }^{13}$. Ze względu na taką konstrukcję i zamknięty katalog możliwych spółek podlegających podziałowi pod definicję „spółki” nie podpada więc forma prawna spółdzielni.

Natomiast w przypadku legalnej definicji „spółki podlegającej podziałowi” ustawodawca europejski zakreślił, że chodzi o spółkę, która w procesie podziału transgranicznego przenosi wszystkie swoje aktywa i pasywa na co najmniej dwie spółki w wypadku pełnego podziału lub przenosi część swoich aktywów i pasywów na co najmniej jedną spółkę w wypadku częściowego podziału lub podziału przez wydzielenie.

O ile wskazane definicje wydają się skonstruowane w przemyślany sposób, o tyle poważne zastrzeżenia budzi definicja „spółki przejmującej” użyta w polskiej wersji językowej dyrektywy 2017/1132 (art. 160b pkt 3). Zgodnie z nią ,spółka przejmu-

13 W odniesieniu do ustawodawstwa polskiego są to: spółka z o.o., spółka akcyjna oraz spółka komandytowo-akcyjna. W przypadku Republiki Czeskiej chodzi o spółkę z o.o. i spółkę akcyjną. 
jąca" to spółka nowo utworzona w toku podziału transgranicznego. Definicja użyta w polskiej wersji językowej dyrektywy jest o tyle niezrozumiała, że przepisy szóstej dyrektywy ${ }^{14}$ rozróżniały podział przez przejęcie (art. 2) od podziału przez utworzenie nowej spółki (art. 21). Co prawda przepis art. 22 szóstej dyrektywy (obecnie art. 156 ust. 1 dyrektywy 2017/1132) przewidywał, że w przypadku podziału przez utworzenie nowej spółki wyrażenie „spółki przejmujące” oznacza każdą z nowo utworzonych spółek, jednakże zakreślał, do celu stosowania jakich konkretnych przepisów pojęcie „spółka przejmująca” będzie obejmować także spółki nowo utworzone. W konsekwencji definicję „spółki przejmującej” użytą w odniesieniu do podziału transgranicznego w przypadku polskiej wersji językowej dyrektywy 2017/1132 należy uznać za błędną. Obecnie polska wersja językowa dyrektywy 2017/1132 zawiera tym samym — w ramach jednego aktu prawnego — dwa różne ujęcia ,spółki przejmującej” w przypadku podziału. Odnośnie do podziałów „krajowych” pojęcie spółki przejmującej obejmuje spółkę przejmującą w przypadku podziału przez przejęcie oraz spółkę nowo utworzoną w wypadku podziału przez utworzenie nowej spółki ${ }^{15}$. Natomiast w odniesieniu do podziałów transgranicznych pojęcie „spółki przejmującej" dotyczy jedynie spółki nowo utworzonej w przypadku transgranicznego podziału przez utworzenie nowej spółki (zarówno w wypadku podziału przez rozdzielenie, jak i podziału przez wydzielenie). Wydaje się, że ta niekonsekwencja językowa z powodzeniem mogłaby zostać skorygowana w odniesieniu do podziału transgranicznego i w miejsce pojęcia „spółka przejmująca” powinno zostać wprowadzone pojęcie „spółka nowo utworzona”, to jest odnoszące się do takiej spółki, która została utworzona wskutek podziału transgranicznego. Co istotne, wspomniana nieścisłość językowa nie jest zauważalna w czeskiej wersji językowej zarówno szóstej dyrektywy, jak i dyrektywy 2019/2121. W czeskich wersjach wspomnianych dyrektyw pojawia się bowiem określenie „spółka następczyni prawna” (czes. nástupnická společnost). W tym zakresie siatka pojęciowa, którą posłużył się ustawodawca europejski, w czeskiej wersji językowej zasadniczo pokrywa się z siatką pojęciową, którą wykorzystał ustawodawca czeski w ustawie o przemianach, z tym zastrzeżeniem że w przypadku transgranicznego podziału używa on określenia „osoba prawna będąca następczynią prawną" (czes. nástupnická právnická osoba) ${ }^{16}$.

\section{POJĘCIE TRANSGRANICZNEGO PODZIAŁU W PRAWIE CZESKIM}

Czeska ustawa o przemianach nie definiuje ani pojęcia krajowego podziału spółek, ani pojęcia transgranicznego podziału spółek ${ }^{17}$. Podobnie jak w przypadku regulacji polskiej w odniesieniu do krajowego podziału spółek ustawodawca cze-

14 Dyrektywa Rady z 17 grudnia 1982 roku dotycząca podziału spółek akcyjnych, Dz.Urz. UE L 378 z 31.12.1982 r., s. 47; dalej: szósta dyrektywa.

15 Zarówno w przypadku podziału przez rozdzielenie, jak i podziału przez wydzielenie.

16 Por. m.in. § 336a lit. a i lit. b PřemZ.

17 Więcej zob. I. Bílá, [w:] I. Štenglová et al., Zákon o přeměnách obchodních společností a družstev. Komentár̆, Praha 2010, s. 726-727. 
ski ograniczył się jedynie do wskazania możliwych sposobów podziału krajowego. Zaznaczył on bowiem w przepisie $\S 243$ ust. 1 PřemZ, że podział może zostać dokonany bądź to $\mathrm{w}$ drodze podziału przez rozdzielenie (czes. rozštěpeni), bądź to w drodze podziału przez wydzielenie (czes. odštěpeni). Ustawodawca czeski przewiduje ponadto we wspomnianym przepisie, że zarówno podział przez rozdzielenie, jak i podział przez wydzielenie może zostać zrealizowany w drodze podziału przez przejęcie albo podziału przez zawiązanie nowych spółek, albo w drodze kombinacji tych dwóch form ${ }^{18}$. Należy podkreślić, że w świetle obowiązującej regulacji czeskiej możliwy jest krajowy podział nie tylko spółek kapitałowych, lecz także spółki jawnej (§ 267-271a PřemZ), spółki komandytowej (§ 272-275 PřemZ) ${ }^{19}$ oraz spółdzielni (§ 320-336 PřemZ).

W taki właśnie sposób czeski ustawodawca sankcjonuje możliwe sposoby krajowego podziału. Jeśli przepisy szczególne o transgranicznym podziale nie stanowią inaczej, do tej odmiany podziału zastosowanie znajdują przepisy o krajowym podziale ${ }^{20}$. Czeska regulacja przewiduje, że na potrzeby ustawy o przemianach jako transgraniczny podział należy rozumieć podział zagranicznej osoby prawnej, wskutek którego prawem właściwym przynajmniej dla jednej z osób prawnych jest albo będzie prawo czeskie (§ 336a lit. a PřemZ), albo podział czeskiej spółki lub spółdzielni, wskutek którego prawem właściwym przynajmniej dla jednej z osób prawnych będzie prawo właściwe państwa członkowskiego innego niż Republika Czeska (§ 336a lit. b PřemZ). Dodatkowym ograniczeniem zakresu podmiotowego transgranicznego podziału jest w prawie czeskim przepis $\S 336 \mathrm{~b}$ ust. 1 PřemZ. Stosownie do jego hipotezy podział transgraniczny jest możliwy jedynie pomiędzy takimi osobami prawnymi, które mogą uczestniczyć w transgranicznym podziale zgodnie z prawem właściwym państwa członkowskiego. Dodatkowo, jeżeli wskutek transgranicznego podziału osoba prawna mająca być następcą prawnym dzielonej osoby prawnej będzie mieć inną formę prawną niż którakolwiek z osób prawnych uczestniczących w podziale przed wpisem do właściwego rejestru, to taki podział nie jest traktowany jako zmiana formy prawnej (przekształcenie $)^{21}$. Taka konstrukcja przyjęta przez ustawodawcę czeskiego będzie więc mieć — z uwagi na zakres podmiotowy krajowego podziału — daleko idące konsekwencje.

18 Ustawodawca czeski wskazuje następujące możliwe formy podziału: podział przez rozdzielenie z utworzeniem nowych spółek (czes. rozštěpeni se vznikem nových společnosti), podział przez rozdzielenie z przejęciem (czes. rozštěpeni sloučením), podział przez wydzielenie z utworzeniem nowej lub nowych spółek (czes. odštěpeni se vznikem nové nebo nových společnosti), podział przez wydzielenie z przejęciem (czes. odštěpeni sloučením).

19 W czeskim piśmiennictwie wskazuje się, że wzorem dla czeskiej regulacji transgranicznego podziału było uregulowanie znajdujące się w prawie fińskim, chociaż odnosi się to wyłącznie do spółek kapitałowych — por. T. Dvořák, op. cit., s. 351, przyp. 267.

20 Zob. na ten temat ibidem, s. 351.

21 Zob. ibidem. 


\section{POSTULATY DE LEGE FERENDA W ODNIESIENIU DO PRZYSZŁEJ POLSKIEJ REGULACJI TRANSGRANICZNEGO PODZIAŁU}

Ustawodawca polski z jednej strony jest ograniczony uregulowaniem podmiotowego zakresu transgranicznego podziału wskazanym w przepisach art. 160a i 160b dyrektywy 2017/1132, z drugiej zaś z uwagi na nieprecyzyjność ustawodawcy europejskiego będzie zmuszony dostosować regulację do już istniejącej na gruncie kodeksu spółek handlowych siatki pojęciowej. Niewskazane wydaje się więc wprowadzenie różnego rozumienia pojęcia „spółka przejmująca” w przypadku podziału, opierając je jedynie na polskiej wersji językowej dyrektywy.

Problematyczny dla polskiego ustawodawcy może być zakres podmiotowy podziału transgranicznego wskazany w art. 160b pkt 1 dyrektywy 2017/1132 przez odesłanie do załącznika II. Podyktowane jest to faktem, że wspomniany załącznik wskazuje w przypadku polskiego ustawodawstwa oprócz spółki z o.o. i spółki akcyjnej również spółkę komandytowo-akcyjną. Ze względu na zakres podmiotowy podziału przewidziany w art. $528 \S 1$ i 2 k.s.h. należy rozważyć, czy w części dotyczącej podziału transgranicznego powinien zostać wprowadzony przepis szczególny umożliwiający dokonanie podziału albo utworzenie wskutek podziału spółki komandytowo-akcyjnej podlegającej prawu polskiemu. W mojej opinii ustawodawca polski powinien kategorycznie wyłączyć możliwość transgranicznego podziału polskiej spółki komandytowo-akcyjnej przede wszystkim z uwagi na subsydiarną odpowiedzialność komplementariuszy. Transgraniczny podział mógłby służyć do obchodzenia polskiej regulacji odpowiedzialności subsydiarnej komplementariuszy i wyprowadzania majątku do zagranicznej nowo zawiązanej spółki, w której dotychczasowi komplementariusze nie pełniliby już funkcji komplementariuszy, a byliby jedynie nieodpowiadającymi za zobowiązania wspólnikami (akcjonariuszami) spółki z o.o. (spółki akcyjnej) albo w ogóle rezygnowaliby z uczestnictwa w spółkach sukcesorkach. W takiej sytuacji wprowadzenie na wzór art. 546 k.s.h. odpowiedzialności spółek uczestniczących w transgranicznym podziale mogłoby być niewystarczające.

Wydaje się, że polski ustawodawca może przy tym skorzystać ze sposobu dookreślenia transgranicznego podziału i na wzór ustawodawcy czeskiego wskazać, co należy rozumieć jako transgraniczny podział. Dodatkowo w celu uniknięcia wątpliwości doktrynalnych należy zastanowić się nad wprowadzeniem analogicznego do czeskiej regulacji przepisu traktującego o możliwości przeprowadzenia transgranicznego podziału jedynie pomiędzy takimi spółkami, które mogą uczestniczyć $\mathrm{w}$ transgranicznym podziale zgodnie z prawem właściwym państwa członkowskiego. W celu ukrócenia sporów doktrynalnych trzeba także rozważyć wprowadzenie uregulowania wskazującego, że nie jest możliwe dokonanie podziału spółki kapitałowej w organizacji, również tej, której kapitał zakładowy został pokryty w całości ${ }^{22}$. Tym samym warto zaproponować wprowadzenie prze-

22 Odmiennie A. Witosz, który twierdził, że spółki w organizacji mają zdolność podziałową. Zob. idem, Zdolność łączeniowa i podziałowa spółek w organizacji, „Prawo Spółek” 2003, nr 10, s. 2-8. 
pisu szczególnego wskazującego, jakie podmioty nie będą mogły uczestniczyć $\mathrm{w}$ transgranicznym podziale. Polski ustawodawca będzie zobowiązany w ramach takiego katalogu uwzględnić nałożony przez ustawodawcę unijnego zakaz podziału spółek działających na zasadzie dywersyfikacji ryzyka, których celem jest zbiorowe inwestowanie kapitału pozyskanego w drodze publicznej oraz spółek, których jednostki uczestnictwa są na żądanie ich posiadaczy odkupywane lub umarzane bezpośrednio lub pośrednio z aktywów tej spółki (art. 160a ust. 3 dyrektywy 2017/1132). Ponadto należy przemyśleć — na wzór czeskiego uregulowania - kwestię wprowadzenia konstrukcji ograniczenia podziału polskiej spółki kapitałowej, jeżeli wskutek jej podziału spółką przejmującą bądź nowo zawiązaną miałaby być zagraniczna forma spółki, dla której ustawodawca polski wyłączył możliwość podziału krajowego (na przykład spółka osobowa). Zapobiegłoby to przyszłym sporom teoretycznym i praktycznym.

Następnie ustawodawca polski będzie musiał rozstrzygnąć kwestię przedmiotowego zakresu podziału transgranicznego. Tym samym stanie on przed problemem, czy przyjąć regulację uwzględniającą jedynie minimalny standard harmonizacji, czy jednak - podobnie jak ma to miejsce w prawie czeskim — rozwiązanie, zgodnie z którym transgraniczny podział może przybrać formę podziału przez utworzenie nowej spółki oraz podziału przez przejęcie.

\section{PRZEBIEG TRANSGRANICZNEGO PODZIAŁU ORAZ JEGO SKUTKI}

\section{REGULACJA UNIJNA. UWAGI OGÓLNE}

W przypadku procedury transgranicznego podziału spółek kapitałowych dochodzi do zastosowania przynajmniej dwóch odmiennych krajowych porządków prawnych. Procedura podziału, w zależności od przyjętej klasyfikacji czynności niezbędnych do jej dokonania, będzie podzielona na kilka faz. Ze względu na klasyfikację czynności dokonywanych przez poszczególne organy spółek uczestniczących w połączeniu oraz organy państwowe można zasadniczo wyróżnić cztery fazy. W świetle tej klasyfikacji postępowanie związane z transgranicznym podziałem będzie wymagać:

- czynności przygotowawczych dokonywanych przez zarządy lub organy administrujące (tak zwana faza menedżerska);

— podjęcia uchwały o podziale przez wspólników (akcjonariuszy) spółki dzielonej i ewentualnie istniejącej spółki przejmującej (tak zwana faza właścicielska);

- kontroli podziału przez uprawnione do tego na podstawie ustawowej kompetencji podmioty: sądy rejestrowe, notariuszy itd. (tak zwana faza kontrolna);

- rejestracji i ogłoszenia o podziale przez właściwy organ: sąd rejestrowy, organ administracji państwowej itp. (tak zwana faza autoryzacji). 
Poszczególne etapy zostały uregulowane w przepisach dyrektywy 2017/1132. Czynności przygotowawcze polegają na przygotowaniu i uzgodnieniu procedury podziału. Będą one obejmować przede wszystkim sporządzenie planu podziału (art. 160d dyrektywy 2017/1132), poddanie go badaniu przez biegłych (art. 160f dyrektywy 2017/1132) oraz przygotowanie sprawozdania uzasadniającego prawne i ekonomiczne aspekty podziału wraz z wyjaśnieniem jego skutków dla pracowników (art. 160e dyrektywy 2017/1132). Należy zaznaczyć, że przepisy dyrektywy 2017/1132 w odniesieniu do transgranicznego podziału przewidują możliwość odstąpienia od wymogu sporządzania opinii biegłego, w przypadku gdy wszyscy wspólnicy spółki dzielonej wyrazili na to zgodę.

Następną fazą transgranicznego podziału jest wspomniana faza właścicielska. Na tym etapie, po zapoznaniu się ze wspomnianymi sprawozdaniami, zgromadzenie wspólników (walne zgromadzenie) podejmuje uchwałę o zatwierdzeniu planu podziału i ewentualnym dostosowaniu aktu założycielskiego (umowy spółki lub statutu) w wypadku podziału przez wydzielenie. Przepisy dyrektywy 2017/1132 przewidują $\mathrm{w}$ odniesieniu do transgranicznego podziału wymóg co do większości głosów (przynajmniej dwie trzecie, jednak nie więcej niż 90\% głosów związanych albo z udziałami lub akcjami, albo z kapitałem subskrybowanym reprezentowanym podczas zgromadzenia wspólników lub walnego zgromadzenia). Ustawodawca europejski, mimo że nie wprowadza wymogu kworum, wskazuje, że większość (dosłownie wartość progowa) dla uchwały o podziale transgranicznym nie może być wyższa od przewidzianej dla uchwały o podziale krajowym (art. 160h ust. 3 dyrektywy 2017/1132).

Wypada podkreślić, że zgromadzenie wspólników (walne zgromadzenie) spółki dzielonej może zastrzec sobie prawo do uzależnienia podziału od wyraźnego zatwierdzenia przez nie warunków uczestnictwa pracowników w spółkach sukcesorkach. Natomiast sama uchwała nie może zostać zaskarżona ze względu na zastrzeżenia dotyczące wyłącznie stosunku wymiany udziałów lub akcji, jak również z uwagi na ustalenie wynagrodzenia $\mathrm{w}$ formie pieniężnej przeznaczonego dla wspólników głosujących przeciwko zatwierdzeniu planu ${ }^{23}$.

Trzecią fazą jest faza kontrolna. Zasadniczo - podobnie jak w przypadku transgranicznego łączenia się spółek - będzie ona przebiegać dwuetapowo. Różnica będzie polegać jedynie na tym, że oba etapy kontroli w wypadku transgranicznego podziału nie będą przebiegać równolegle w dwóch państwach członkowskich, ale będą następować po sobie. Pierwszy etap działań kontrolnych będzie wykonywać organ właściwy dla przeprowadzenia jej w stosunku do spółki dzielonej (tak zwana kontrola legalności podziału). Natomiast drugi etap kontroli będzie dotyczyć zbadania tej części procedury podziału odnoszącej się do ukończenia po-

${ }^{23}$ Należy tutaj zaznaczyć, że do polskiej wersji językowej przepisu art. 160d lit. p dyrektywy 2017/1132 wkradł się błąd, ponieważ przepis ten powinien odsyłać do art. 160i zamiast do powołanego tam art. 1601. 
działu transgranicznego, którą będą już regulować ustawodawstwa państw członkowskich spółek nowo powstałych. Kontrola ta będzie mogła być dokonywana przez sąd, notariusza bądź inny organ państwowy właściwy do przeprowadzenia kontroli wskazany przez dane ustawodawstwo krajowe.

Ostatni etap będzie polegać już na rejestracji transgranicznego podziału przeprowadzonego zgodnie z prawem właściwym dla spółki dzielonej (pierwszy etap kontroli) oraz prawem właściwym dla spółki nowo zawiązanej (drugi etap kontroli). Dopiero po przeprowadzeniu kontroli drugiego etapu podział transgraniczny może stać się skuteczny. Ustawodawca europejski obliguje przy tym państwa członkowskie, aby określiły w tym celu konkretną datę (art. 160q dyrektywy 2017/1132).

Inny rodzaj klasyfikowania faz postępowania w sprawie transgranicznego podziału opiera się na rozgraniczeniu czynności na podstawie stosowania właściwego prawa krajowego do procedury podziałowej. Na gruncie takiej systematyzacji trzeba rozróżnić dwie fazy — przygotowawczą (początkową) i finalną (końcową).

Faza przygotowawcza będzie przebiegać na podstawie prawa właściwego dla spółki dzielonej. Będzie się kończyć wydaniem zaświadczenia ostatecznie potwierdzającego należyte dopełnienie czynności i formalności poprzedzających dokonanie podziału transgranicznego.

Faza finalna transgranicznego podziału będzie natomiast przebiegać równocześnie w tylu krajowych porządkach prawnych, ile nowych spółek, które będą podlegać różnym państwom członkowskim, powstanie. Dodatkowo w przypadku podziału przez wydzielenie w związku z obniżeniem kapitału zakładowego faza finalna będzie odbywać się w ramach porządku krajowego właściwego dla spółki dzielonej. Tym samym faza finalna będzie zawsze podlegać przynajmniej dwóm różnym prawom właściwym państw członkowskich, w których swoje siedziby będą mieć spółka dzielona i nowo zawiązana (nowo zawiązane).

Kwestia skutków w odniesieniu do transgranicznego podziału znalazła się w przepisie art. 160r dyrektywy 2017/1132. Ustawodawca europejski w odniesieniu do wspomnianych sposobów podziału zasadniczo wskazuje trzy podstawowe skutki objęte tak zwaną sukcesją uniwersalną częściową ${ }^{24}$ : sukcesję materialnoprawną (art. 160r ust. 1 lit. a; ust. 2 lit. a oraz ust. 3 lit. a); nabycie członkostwa w spółce nowo zawiązanej przez część dotychczasowych wspólników spółki dzielonej (art. 160r ust. 1 lit. b; ust. 2 lit. b oraz ust. 3 lit. b) oraz sukcesję w zakresie stosunków pracy (art. 160r ust. 1 lit. c; ust. 2 lit. c oraz ust. 3 lit. c). W przypadku

${ }^{24}$ Więcej na temat sukcesji uniwersalnej częściowej zob. P. Pinior, [w:] Kodeks spótek handlowych. Komentarz, red. J.A. Strzępka, Warszawa 2015, s. 1315-1316; idem, Podziat spótek kapitałowych w prawie polskim i niemieckim, Warszawa 2003, s. 141 n.; M. Rodzynkiewicz, [w:] Kodeks spółek handlowych, t. 4. Łaczenie, podział i przekształcanie spółek. Przepisy karne. Komentarz Art. 491-633, red. A. Opalski, Warszawa 2016, s. 483-484; A. Szumański, Komentarz do art. 531 KSH, Nb 9-10, [w:] S. Sołtysiński et al., Kodeks spółek handlowych, t. 4. Eaczenie, podziat i przeksztatcanie spótek. Przepisy karne. Komentarz do art. 491-633, Warszawa 2012, Legalis. 
podziału przez rozdzielenie ustawodawca europejski wskazuje ponadto, że dochodzi do ustania bytu prawnego spółki dzielonej (art. 160r ust. 1 lit. d).

O ile przebieg procedury transgranicznego podziału jest uregulowany stosunkowo przejrzyście w ramach dyrektywy 2017/1132, o tyle transpozycja przepisów jedynie w ramach minimalnego standardu harmonizacyjnego może w przyszłości wywołać w polskiej doktrynie oraz praktyce wiele istotnych wątpliwości. Do najważniejszych niewątpliwie będą należeć takie kwestie, jak: forma planu transgranicznego podziału, sposób podejmowania uchwały o podziale oraz regulacja wydawania zaświadczenia potwierdzającego dopuszczalność podziału. Mając na uwadze wskazane kwestie oraz fakt uregulowania problematyki transgranicznego podziału przez prawo czeskie, rozwiązania przyjęte na gruncie tego ostatniego mogą posłużyć jako wzór dla ustawodawcy polskiego.

\section{REGULACJA CZESKA}

Plan podziału transgranicznego (czes. projekt přeshraničního rozděleni) jest podstawowym aktem na etapie dokonywania czynności przygotowawczych. Sporządzenie go stanowi obowiązkową czynność w procedurze transgranicznego podziału. Jak wskazuje się w literaturze ${ }^{25}$, ze względu na to, że ustawodawca czeski w przepisie $\S 336 \mathrm{c}$ PřemZ posłużył się konstrukcją, w której wskazano jedynie elementy szczególne, jakie ma zawierać projekt transgranicznego podziału, w celu jego przygotowania należy sięgnąć do treści krajowego planu podziału (§ 250 PřemZ) oraz ogólnej regulacji tak zwanego projektu przemiany (czes. projekt přeměny $)^{26}$. Projekt podziału transgranicznego - stosownie do § 14 ust. 1 PřemZ - musi zostać sporządzony w formie pisemnej. Należy przy tym podkreślić, że regulacja czeska przewiduje, że jeśli statut osobowy spółki przejmującej bądź nowo zawiązanej ma podlegać prawu czeskiemu, projekty transgranicznego podziału zostały przygotowane w kilku wersjach językowych różniących się od siebie, za decydujące uważa się brzmienie projektu w języku czeskim, chyba że porozumienie pomiędzy uczestniczącymi w podziale spółkami przewiduje co innego ( $\$ 59 \mathrm{f}$ ust. 1 PřemZ).

Podjęcie uchwały o podziale transgranicznym jest kluczowym etapem całej procedury. Przepisy dotyczące transgranicznego podziału nie przewidują szczegółowych zasad podejmowania uchwał o podziale. Ze względu na systematykę ustawy o przemianach do podejmowania uchwał o połączeniu transgranicznym z udziałem czeskiej spółki kapitałowej należy więc stosować przepisy części pierwszej tej ustawy, zawierające postanowienia ogólne dotyczące podstawowych

${ }^{25}$ Zob. J. Šafránek et al., Zákon o preměnách obchodnich společností a družstev: Praktický komentár̆, Praha 2019, s. 432.

${ }^{26}$ Projekt przemiany stanowi ogólną regulację znajdującą zastosowanie do regulacji szczegółowych projektów, to jest sporządzanych w przypadku połączenia, podziału czy zmiany formy prawnej. 
zasad podejmowania uchwał o przemianach spółek ${ }^{27}$. W przypadku uchwał o podziale podejmowanych w czeskiej spółce $\mathrm{z}$ o.o. oraz w spółce akcyjnej znajdą zastosowanie kolejno $\S 17$ oraz $\S 21$ PřemZ. Do podjęcia uchwały o transgranicznym podziale wymagana będzie kwalifikowana większość trzech czwartych głosów ( $\$ 17$ ust. 2 oraz $\S 21$ ust. 2 PřemZ). Umowa spółki z o.o. bądź statut spółki akcyjnej może jednakże przewidywać surowsze warunki w zakresie większości. $\mathrm{Z}$ uwagi na to, że czeski ustawodawca milczy w ustawie o przemianach spółek handlowych i spółdzielni co do kworum, trzeba stosować w tej kwestii przepisy ustawy o korporacjach ${ }^{28}$.

Kolejnym istotnym zagadnieniem jest wydanie zaświadczenia o zgodności z prawem przeprowadzonego krajowego etapu podziału transgranicznego. Wspomniane zaświadczenie w świetle ustawodawstwa czeskiego zobowiązany jest wydać notariusz. Zaświadczenie może zostać wydane, jeśli spółka dzielona przedłoży wiele dokumentów wskazanych w rozporządzeniu Ministra Sprawiedliwości Republiki Czeskiej z 9 grudnia 2011 roku w sprawie dokumentów, które czeska osoba prawna uczestnicząca w przemianie transgranicznej powinna przedłożyć notariuszowi w celu wydania zaświadczenia o transgranicznym podziale (Zák. 416/2011). W przypadku gdy uczestnicząca w podziale transgranicznym czeska spółka kapitałowa nie przedłoży któregokolwiek ze wskazanych dokumentów, notariusz odmówi dokonania czynności notarialnej i wydania zaświadczenia o zgodności.

\section{UWAGI KOŃCOWE}

W świetle przedstawionych rozważań ustawodawca polski stoi przed koniecznością szczegółowego uregulowania procedury podziału transgranicznego. Uwagi poczynione na łamach niniejszego opracowania mogą posłużyć jako głębsza refleksja przed zbyt szybkim i nieprzemyślanym uregulowaniem tej problematyki. Ze względu na to, że procedura transgranicznego podziału została obecnie uregulowana w prawie czeskim, ustawodawca polski może wykorzystać niektóre przewidziane tam rozwiązania. Do istotnych zagadnień związanych z podziałem

27 Więcej na ten temat J. Dědič, Přeměny obchodnich společností a družstev pro podnikatelskou praxi, Praha 2012, s. 361.

28 Zgodnie z przepisem $\S 169$ ust. 1 czeskiej ustawy z 25 stycznia 2012 roku o spółkach handlowych i spółdzielniach (czes. Zákon o obchodních společnostech a družstvech, Zák. č. 90/2012 Sb., dalej: czeska ZOK) walne zgromadzenie wspólników spółki z o.o. jest legitymowane do skutecznego podjęcia uchwały, jeżeli na jej posiedzeniu są obecni wspólnicy mający co najmniej połowę wszystkich głosów w spółce. Walne zgromadzenie akcjonariuszy czeskiej spółki akcyjnej w myśl $\S 412$ ust. 1 czeskiej ZOK jest legitymowane (zdolne) do skutecznego podjęcia uchwały, jeżeli na jego posiedzeniu są obecni akcjonariusze, których wartość nominalna akcji bądź liczba jest większa niż 30\% kapitału zakładowego spółki. Zarówno umowa spółki z o.o., jak i statut spółki akcyjnej mogą uregulować tę kwestię inaczej. 
transgranicznym, które powinny zostać rzetelnie uregulowane w prawie polskim, niewątpliwie należą między innymi forma i treść planu podziału transgranicznego, sposób podejmowania uchwały o podziale oraz wystawianie zaświadczenia o zgodności z prawem polskim krajowego etapu procedury podziałowej.

Ze względu na szczegółową treść planu podziału transgranicznego wskazaną obecnie w art. 160d dyrektywy 2017/1132 należy przyjąć — w celu uniknięcia zarzutów niedostosowania regulacji polskiej do prawa unijnego - że w przepisach kodeksu spółek handlowych powinna znaleźć się analogiczna regulacja dotycząca treści planu podziału transgranicznego. Ustawodawca polski musi jednak wziąć pod uwagę, że do przepisu art. 160d lit. p polskiej wersji językowej dyrektywy 2017/1132 wkradł się błąd, ponieważ odsyła on do art. 1601, który dotyczy zasad uczestnictwa pracowników. W przypadku pozostałych dwudziestu trzech wersji językowych dyrektywy nie ma bowiem tego błędu. W związku z tym w regulacji krajowej ustawodawca powinien odnieść się do prawa do otrzymania wynagrodzenia (dopłat) przez wspólników nieuczestniczących dalej w którejkolwiek ze spółek, a nie - jak ma to miejsce w polskiej wersji językowej dyrektywy — do zasad uczestnictwa pracowników. Kolejną istotną kwestią jest forma planu podziału transgranicznego. Zasadniczo wydaje się, że nie ma potrzeby, aby przewidywać w tym przypadku formę surowszą niż ta, która została zastrzeżona dla krajowego planu podziału spółki. Tym samym wydaje się, że podobnie jak ma to miejsce w prawie czeskim, forma pisemna będzie tutaj wystarczająca. Polski ustawodawca powinien ponadto rozważyć wprowadzenie regulacji analogicznej do czeskiej, która przewiduje możliwość stosowania tak zwanej klauzuli językowej, jeżeli plan podziału dla spółki dzielonej został sporządzony w wersji językowej innej niż polska.

W przypadku uchwały o podziale ustawodawca europejski wprowadził minimalną i maksymalną większość do jej podjęcia, pomijając kwestię ewentualnego kworum. Zastrzegł przy tym, że większość dla uchwały o podziale transgranicznym nie może być wyższa od przewidzianej dla uchwały o podziale krajowym. W takim wypadku należy rozważyć, czy ustawodawca polski dla uchwały o transgranicznym podziale powinien przewidzieć łagodniejsze wymogi niż te wskazane w art. 541 k.s.h. W mojej opinii byłoby to jednak niewskazane, między innymi ze względu na zakaz wzruszania uchwały o podziale transgranicznym po wpisie podziału do odpowiedniego rejestru (art. 160u zd. 1 dyrektywy 2017/1132). Tym samym w stosunku do podziału transgranicznego wymogi zostałyby znacznie bardziej złagodzone niż w przypadku krajowego podziału.

Trzeba zauważyć, że uwagi podniesione w wypadku regulacji czeskiej dotyczące wydawania zaświadczenia o zgodności podziału z prawem krajowym zasadniczo nie będą mogły w pełni zostać zastosowane do proponowanej regulacji polskiej. Ze względu na sposób polskiej regulacji jedynym właściwym organem do wydania tego zaświadczenia będzie bowiem nie notariusz, lecz sąd rejestrowy. Mając jednak na uwadze nieścisłość językową, która znalazła się w polskiej regu- 
lacji dotyczącej transgranicznego połączenia (art. $516^{12} \S 3$ k.s.h.), należy wysunąć postulat de lege ferenda, aby w uregulowaniu podziału znalazło się sformułowanie „wpisuje do rejestru wzmiankę o zakończeniu wobec spółki pierwszego etapu procedury transgranicznego podziału podlegającego prawu polskiemu"29. Podyktowane jest to tym, że wydanie takiego zaświadczenia nie kończy procedury podziału, a jedynie pierwszą fazę kontrolną.

\title{
THE NEED FOR IMPLEMENTATION OF THE PROVISIONS OF CROSS-BORDER DIVISIONS IN POLISH LAW (REMARKS ON THE BACKGROUND OF THE EXISTING CZECH REGULATIONS)
}

\author{
Summary
}

The Polish legislator is presented with the necessity of implementing a new regulation with regards to cross-border divisions of companies. He shall bring into force the regulations required to comply with Directive (EU) 2019/2121 by 31.01.2023. With regards to this issue, the main aim of this paper is to analyse the procedure of cross-border divisions proposed by the European legislator in the previously mentioned Directive in comparison to the Czech regulations that are currently in force. In the following pages of this article, references have been made to the place of the provisions, the legal definition of cross-border divisions, and the scope of regulation.

Keywords: cross-border divisions, implementation of Directive 2019/2121, Czech regulations, legal definition of divisions

\section{BIBLIOGRAFIA}

Bílá I., [w:] I. Štenglová, I. Bílá, B. Havel, P. Kuhn, I. Štenglová, I. Bílá, B. Havel, R. Brázda, J. Hejda, A. Zídek, Zákon o přeměnách obchodnich společností a družstev. Komentár̆, Praha 2010.

Dědič J., Novinky v právní úpravě preměn obchodních společností a družstev, „Obchodněprávní revue" 2012, nr 1.

Dědič J., Přeměny obchodních společností a družstev pro podnikatelskou praxi, Praha 2012.

Dvořák T., Přeměny obchodnich korporací, Praha 2015.

Glos J., O přeměnách obchodnich společností, „Právní prakse” 1942-1943.

Król R., Dopuszczalność przeprowadzenia transgranicznego podziału spółki, PPH 2017, nr 4.

Napierała J., [w:] System Prawa Handlowego, t. 2b. Prawo spótek handlowych, red. A. Szumański, Warszawa 2019.

Pelikán R., [w:] S. Černá, I. Štenglová, I. Pelikánová, Právo obchodnich korporací, Praha 2015.

Pelikán R., Zákon o preměnách obchodních společností a družstev. Komentář, t. 1. § 1-179, Praha 2010. Pinior P., [w:] Kodeks spółek handlowych. Komentarz, red. J.A. Strzępka, Warszawa 2015.

Pinior P., Podziat spótek kapitałowych w prawie polskim i niemieckim, Warszawa 2003.

29 Por. w odniesieniu do transgranicznego połączenia M. Żaba, Skutki transgranicznego łaczenia się spółek kapitałowych (studium prawnoporównawcze ustawodawstwa polskiego, czeskiego i stowackiego), Warszawa 2019, s. 94-95. 
Rodzynkiewicz M., [w:] Kodeks spółek handlowych, t. 4. Łaczenie, podziat i przeksztatcanie spółek. Przepisy karne. Komentarz - Art. 491-633, red. A. Opalski, Warszawa 2016.

Szumański A., [w:] S. Sołtysiński, A. Szajkowski, A. Szumański, J. Szwaja, M. Tarska, R. Zawłocki, Kodeks spótek handlowych, t. 4. Łączenie, podziat i przeksztatcanie spótek. Przepisy karne. Komentarz do art. 491-633, Warszawa 2012, Legalis.

Šafránek J., Laštovičková L., Podškubka T., Hlaváč J., Pěsna L., Zákon o přeměnách obchodnich společností a družstev: Praktický komentářr, Praha 2019.

Witosz A., Zdolność tączeniowa i podziałowa spótek w organizacji, „Prawo Spółek” 2003, nr 10.

Żaba M., Skutki transgranicznego łączenia się spótek kapitałowych (studium prawnoporównawcze ustawodawstwa polskiego, czeskiego i słowackiego), Warszawa 2019. 